\title{
Isolation and Characterization of Rhizobacteria from Composts That Suppress the Severity of Bacterial Leaf Spot of Radish
}

\author{
M. S. Krause, T. J. J. De Ceuster, S. M. Tiquia, F. C. Michel Jr., L. V. Madden, and H. A. J. Hoitink
}

First, second, fifth, and sixth authors: Department of Plant Pathology, The Ohio State University/OARDC, 1680 Madison Ave., Wooster 44691; and third and fourth authors: Department of Food, Agricultural, and Biological Engineering, The Ohio State University/OARDC, 1680 Madison Ave., Wooster 44691.

Current address of M. S. Krause and T. J. J. De Ceuster: Scientia Terrae Research Institute, Fortsesteenweg 30, B-2860 St.-Katelijne-Waver, Belgium; and S. M. Tiquia: Oak Ridge National Laboratory, P.O. Box 2008, MS6038, Bethel Valley Road, Oak Ridge, TN 37831.

Accepted for publication 23 April 2003.

\begin{abstract}
Krause, M. S., De Ceuster, T. J. J., Tiquia, S. M., Michel, F. C., Jr., Madden, L. V., and Hoitink, H. A. J. 2003. Isolation and characterization of rhizobacteria from composts that suppress the severity of bacterial leaf spot of radish. Phytopathology 93:1292-1300.

Composts can induce systemic resistance in plants to disease. Unfortunately, the degree of resistance induced seems highly variable and the basis for this effect is not understood. In this work, only 1 of 79 potting mixes prepared with different batches of mature, stabilized composts produced from several different types of solid wastes suppressed the severity of bacterial leaf spot of radish caused by Xanthomonas campestris pv. armoraciae compared with disease on plants produced in a nonamended sphagnum peat mix. An additional batch of compostamended mix that had been inoculated with Trichoderma hamatum 382 $\left(\mathrm{T}_{382}\right)$, which is known to induce systemic resistance in plants, also

amended mixes that suppressed bacterial leaf spot were able to significantly suppress the severity of this disease when used as inoculum in the compost-amended mixes. The most effective strains were identified as Bacillus sp. based on partial sequencing of $16 \mathrm{~S}$ rDNA. These strains were significantly less effective in reducing the severity of this disease than $\mathrm{T}_{382}$. A combined inoculum consisting of $\mathrm{T}_{382}$ and the most effective rhizobacterial Bacillus strain was less effective than $\mathrm{T}_{382}$ alone. A drench applied to the potting mix with the systemic acquired resistance-inducing chemical acibenzolar- $S$-methyl was significantly more effective than $T_{382}$ in several, but not all tests. We conclude that systemic suppression of foliar diseases induced by compost amendments is a rare phenomenon. Furthermore, inoculation of compost-amended potting mixes with biocontrol agents such as $\mathrm{T}_{382}$ that induce systemic resistance in plants can significantly increase the frequency of systemic disease control obtained with natural compost amendments.
\end{abstract} suppressed the disease. A total of 11 out of 538 rhizobacterial strains isolated from roots of radish seedlings grown in these two compost-

Composts are used widely by the nursery industry to suppress diseases caused by soilborne plant pathogens $(12,19)$. They are particularly effective for suppression of root rots caused by Pythium and Phytophthora spp. in container media used for the production of nursery crops (18). Microbiostasis and parasitism seem to be the key mechanisms by which these root rots are suppressed $(6,8,28)$. However, systemic induced resistance also can play a role in the biological control of soilborne diseases provided by compost amendments $(33,56)$. This systemic effect may explain why incorporation of composts into field soils or container media may also suppress the severity of diseases caused by plant pathogens that infect aboveground plant parts $(1,11,45,50,56,57)$. Induced systemic resistance (ISR) has been shown to play a role in suppression of plant pathogens that colonize aerial plant parts $(33,57)$. For example, Zhang et al. (57) showed that inoculation of a compost-amended potting mix with Trichoderma hamatum 382 $\left(\mathrm{T}_{382}\right)$ triggered an indirect effect in Arabidopsis against bacterial speck and its pathogen Pseudomonas syringae pv. maculicola and in cucumber against anthracnose caused by Colletotrichum obiculare. This compost-mediated systemic induced resistance correlated with increased $\beta$-1,3-glucanase activity but not until after these plants had been challenged with the pathogen. This suggested that these composts elicited ISR $(34,49,54)$ rather than

Corresponding author: H. A. J. Hoitink; E-mail address: hoitink.1@osu.edu

Publication no. P-2003-0818-01R

(C) 2003 The American Phytopathological Society
Additional keyword: Raphanus sativus. systemic acquired resistance (SAR) in plants $(15,26)$. More recently, Pharand et al. (33) corroborated this finding by showing that incorporation of composted paper mill sludge into a peatbased potting mix induced the formation of physical barriers at infection sites in tomato which limited colonization of the host by Fusarium oxysporum f. sp. radicis-lycopersici. In contrast, the pattern of colonization in plants grown in a sphagnum peat mix where severe disease developed was similar to that in plants produced in hydroponics systems where severe losses caused by Fusarium crown rot are not uncommon unless specific control strategies are applied (7).

Unfortunately, composts are highly variable in their suppressive effects against foliar diseases (11,56,57). Microbial biocontrol agents in composts that induce this effect have not been identified. With the exception of some Bacillus strains, biocontrol agents in general do not survive the high temperature phase of the composting process (24). This beneficial microflora colonizes composts after peak heating during curing of composts. Specific inoculants have been proposed to enhance this process $(24,32)$. Inoculation of compost-amended potting mixes with microorganisms that can trigger ISR also seems to enhance systemic activity $(33,57)$. For example, Pythium oligandrum was more effective in the control of Fusarium crown rot of tomato in a compost-amended mix than in the control peat mix (33). One of the goals of this research was to isolate and identify rhizobacteria from composts that most effectively suppress foliar diseases of plants. A second goal was to develop mixed microbial inoculants with $\mathrm{T}_{382}$ which induce ISR in plants (16). Mixed inoculants have been reported to improve systemic control of foliar diseases of plants (38). 
Apart from the microorganisms that colonize composts after peak heating, the decomposition level or stability of the organic matter in composts seems to contribute to compost-induced systemic resistance as reviewed recently for biological control of diseases caused by soilborne plant pathogens (11). Potting mixes prepared with fresh, undecomposed organic wastes such as fresh paper mill sludge (45), or with highly stabilized sources of organic matter that are low in microbial carrying capacity such as $\mathrm{H}_{4}$ sphagnum peat (von Post decomposition scale; 37), do not support systemic effects $(33,56)$. This supports earlier reports on the role of substrate composition in sustained suppression of diseases caused by soilborne plant pathogens (18). During composting, readily available carbon sources are destroyed, whereas lignin and lignin-protected cellulose are conserved (9). The organic fraction in cured composts, therefore, consists largely of lignin, microbial biomass, and humic substances. It is not surprising, therefore, that lignin and lignin-protected cellulose fractions in potting mixes have been shown to determine the longevity of the disease-suppressive effect against Pythium root rot $(6,44)$. Therefore, organic matter decomposition level, quite apart from microorganisms that colonize composts after peak heating, should be considered in any evaluation of systemic resistance induced by composts.

Composts may supply significant quantities of essential plant nutrients, which varies depending on with the waste materials from which composts are produced (41). Not surprisingly, fertility effects of composts on disease severity can be significant (13). For example, iron affects systemic resistance induced by rhizobacteria (36). Therefore, any comparison of SR-activity induced by composts should also consider fertility. The foregoing reveals why the effects of compost amendments on foliar disease severity can be inconsistent and that systemic induced resistance itself has been referred to as "a slippery concept" of disease control (17).

The first objective of this research was to determine the frequency by which different types and batches of cured composted solid wastes widely available in the United States suppress the severity of foliar diseases of plants. The second objective was to isolate and identify rhizobacteria from compost-amended substrates that reduce the severity of foliar diseases in plants. The third objective was to determine whether mixtures of the most efficacious rhizobacterial strains with $\mathrm{T}_{382}$ would be more effective than single inoculants alone. Bacterial leaf spot of radish was used as a model system. Only stabilized, cured composts for which fertility guidelines were available were tested in this research. A preliminary report on this work was published previously (21).

\section{MATERIALS AND METHODS}

Composts and potting mixes. To obtain information on the ability of natural composts to reduce the severity of foliar diseases of plants, a total of 79 different batches of mature composts were collected from several different compost producers across the United States. These producers prepared composts from the following solid waste groups: (i) pine bark (four sources); (ii) municipal biosolids (two sources); (iii) yard wastes mixed with dairy, horse, and poultry manures (one source); (iv) vegetable cannery wastes mixed with duck manure, yard wastes, and reed canary grass straw (one source); (v) a vermicompost prepared from food wastes; and (vi) a vermicompost prepared from swine manure solids. One batch of composted pine bark was received as a complete potting mix from Earthgro Inc. (Lebanon, CT), where it had been inoculated with the biocontrol agents $\mathrm{T}_{382}$ and Chryseobacterium gleum $299\left(\mathrm{C}_{299}\right)$ to induce suppression to Rhizoctonia damping-off (22). The 79 different batches of composts were collected during curing of composts when temperatures had begun to decline. Thus, these natural composts had become colonized after peak heating by mesophyllic microorganisms to maximize the potential for natural suppression of Pythium and
Rhizoctonia damping-off $(8,22)$ and possibly also foliar diseases. The chemical properties of the compost samples were determined by the STAR Analytical Laboratory of the Ohio State University, Wooster, as specified by the U.S. Composting Council (48).

A low-in-microbial-carrying capacity "dark peat mix" that is naturally conducive to Pythium damping-off and root rots (6) and that does not induce systemic resistance in plants $(56,57)$ was prepared by blending dark $\left(\mathrm{H}_{4}\right.$ on the von Post decomposition scale) sphagnum peat (37) with coarse horticultural grade perlite $(3: 2$, $\mathrm{vol} / \mathrm{vol}$ ) and $1.1 \mathrm{~g}$ of superphosphate, $1.1 \mathrm{~g}$ of $\mathrm{KNO}_{3}, 1.1 \mathrm{~g}$ of gypsum, and a 3:2 ratio of dolomitic lime and calcium carbonate (<100 mesh) per liter of mix (pH 5.5 to 5.8) as described previously (22). All compost types, other than the composted pine bark, were blended into this peat mix at a volumetric ratio of 5 to $15 \%$ depending on the nutrient concentrations projected to be released by the specific batch of compost, based on chemical properties of the compost determined by the STAR Analytical Laboratory. Finally, a composted pine bark-amended potting mix, referred to hereafter as composted pine bark mix, was prepared by blending any one of the four different sources of composted pine bark with medium grade horticultural vermiculite and coarse horticultural grade perlite at a volumetric ratio of 7:7:5:1. This mix was amended further with $0.73 \mathrm{~g}$ of nitroform slow release fertilizer (38-0-0, N-P-K), $0.55 \mathrm{~g}$ of superphosphate (0-45-0, N-P$\mathrm{K}), 0.82 \mathrm{~g}$ of $\mathrm{FeSO}_{4}$ (anhydrous), $0.57 \mathrm{~g}$ of $\mathrm{MgSO}_{4}$ (anhydrous), $0.02 \mathrm{~g}$ of $\mathrm{ZnSO}_{4}, 0.01 \mathrm{~g}$ of $\mathrm{CuSO}_{4}$, and $2.77 \mathrm{~g}$ of gypsum per liter of mix. The $\mathrm{pH}$ of the mixes ranged from 5.5 to 5.8. The electrical conductivity in the saturated paste extract of the mixes was $<2 \mathrm{ds}$ $\mathrm{m}^{-1}$. The air capacity of all potting mixes in pots $(10 \mathrm{~cm}$ in height $)$ after saturation with water followed by drainage was $>20 \%$ (vol/vol). The moisture content of all mixes was adjusted to approximately $50 \%(\mathrm{wt} / \mathrm{wt})$. The mixes were incubated at $25^{\circ} \mathrm{C}$ for 5 days before bioassays were performed to allow mesophyllic microorganisms to fully colonize and thus induce a "natural" degree of suppression as determined by the carrying capacity of the mix (18). To reduce or destroy biocontrol agents naturally present in these potting mixes, a 2-liter sample of each mix was heated for 5 days at $60^{\circ} \mathrm{C}(24)$.

Bacterial leaf spot bioassay. A bacterial leaf spot of radish (Raphanus sativus L. cv. Cabernet) bioassay was used to determine the ability of the 79 different batches of compost-amended potting mixes to induce systemic resistance in plants. The dark peat mix and the heated composted pine bark mixes served as controls in the radish bioassays in which the 79 different batches of composts were screened for their ability to suppress the severity of leaf spot. The foliage of radish seedlings was inoculated with strain 704b of Xanthomonas campestris pv. armoraciae which is naturally resistant to streptomycin sulfate (39). Radish seeds were planted $1 \mathrm{~cm}$ deep in 10-cm-diameter 400-ml polystyrene foam pots (10 seeds per pot; five replicates per treatment). Slow release fertilizer (15-9-12, N-P-K plus minors, The Scotts Company, Marysville, $\mathrm{OH}$ ) was incorporated before planting into the dark peat and composted pine bark mixes at a rate of $10.5 \mathrm{~g}$ per liter of mix. To avoid impacts of fertility introduced with the different types of composts into potting mixes on the severity of bacterial leaf spot, the foliage of 15-day-old radish seedlings grown in each mix was analyzed for concentrations of major and minor essential plant nutrients. The quantity of slow release fertilizer added per liter of mix prepared with the composted manures and biosolids was then adjusted to establish foliar nutrient concentrations within the range recommended for radish (35). Pots were incubated for 7 days in a greenhouse at 22 to $25^{\circ} \mathrm{C}$ under a combination of sunlight and supplemental lighting $\left(>225 \mu \mathrm{E} \mathrm{m} \mathrm{m}^{-2} \mathrm{~s}^{-1}\right.$, $12 \mathrm{~h} \mathrm{day}^{-1}$ ) and irrigated with tap water as needed. The number of seedlings per pot was reduced at this time to five healthy plants of similar size and growth stage. Three days thereafter, pots were transferred to growth chambers at $23^{\circ} \mathrm{C}, 85$ to $95 \%$ relative humidity $(\mathrm{RH})$, and $12 \mathrm{~h}$ of illumination $\left(225 \mu \mathrm{E} \mathrm{m}^{-2} \mathrm{~s}^{-1}\right)$ per day. 
Seedlings were then inoculated with a cell suspension of $X$. campestris pv. armoraciae $704 \mathrm{~b}$ that was produced from a culture grown for $48 \mathrm{~h}$ at $25^{\circ} \mathrm{C}$ on a rotary shaker $(90 \mathrm{rpm})$ in sterile sucrose peptone broth (SPB) (20 g of sucrose and $5 \mathrm{~g}$ of Bacto peptone per liter of distilled water). The cultures were centrifuged $(3,840 \times g, 5 \mathrm{~min})$ and cells were resuspended to a concentration of $3.3 \times 10^{6} \mathrm{ml}^{-1}$ in autoclaved tap water containing a wetting agent $(0.02 \%$ Silwet L-77; OSi Specialties, Danbury, CT). This suspension was sprayed until runoff onto the first two fully expanded true leaves of radish seedlings. The population of $X$. campestris pv. armoraciae $704 \mathrm{~b}$ established on the foliage was verified by dilution plating on SPB agar medium containing $150 \mathrm{mg}$ of streptomycin sulfate per liter (SPAS). Control plants were sprayed with autoclaved tap water containing $0.02 \%$ Silwet L-77. This concentration of Silwet L-77 did not affect disease severity or cause symptoms of phytotoxicity. The RH in the growth chamber remained at 85 to $95 \%$ for $48 \mathrm{~h}$ after inoculation and was reduced thereafter to 55 to $60 \%$. Five days after inoculation when symptoms of bacterial spot had fully developed, the first true leaves of each radish seedling were rated for disease severity on a 1-to- 6 scale: $1=$ symptomless leaf, $2=$ few lesions to $10 \%$ of leaf area affected, $3=10$ to $25 \%$ of leaf area affected, $4=$ 25 to $50 \%$ of leaf area affected, $5=50$ to $75 \%$ of leaf area affected, and $6=>75 \%$ of leaf area affected by lesions or dead leaf. The rating values were converted to percentages by using the midpoint of the severity range for each rating.

Isolation and identification of rhizobacteria that reduced the severity of bacterial leaf spot. Three different procedures were used to isolate rhizobacteria from roots of radish seedlings grown in compost-amended potting mixes that significantly $(P \leq$ $0.05)$ reduced the severity of bacterial leaf spot. In the first procedure, potting mix particles were rinsed from $3-\mathrm{cm}$ root tip sections removed from each of three 7-day-old radish seedlings grown in a potting mix that significantly reduced the severity of the disease in the screening trials. These root sections were comminuted separately with a Ten Broeck homogenizer in $0.45 \mathrm{ml}$ of sterilized dilution buffer, $\mathrm{pH} 7.2$, containing $7 \mathrm{~g}$ of $\mathrm{K}_{2} \mathrm{HPO}_{4}$ and $3 \mathrm{~g}$ of $\mathrm{KH}_{2} \mathrm{PO}_{4}$ per liter of distilled water and $0.15 \%$ (vol/vol) agar (Becton Dickinson, Sparles, MD). The suspension was serially diluted in the dilution buffer and plated in triplicate on $0.1 \times$ trypticase soy broth agar (TSBA; Becton Dickinson). In a second procedure, the same comminuted root samples were heated $20 \mathrm{~min}$ to $80^{\circ} \mathrm{C}$ to destroy vegetative cells and thus facilitate isolation of heat-resistant, spore-forming bacteria on $0.1 \times$ TSBA. In a third procedure based on that developed for recovery of endophytic rhizobacteria by Musson et al. (30), individual root tips were surface-sterilized for $30 \mathrm{~s}$ in $10 \mathrm{ml}$ of $20 \% \mathrm{H}_{2} \mathrm{O}_{2}$ solution, rinsed twice in $10 \mathrm{ml}$ of autoclaved tap water, and immersed for $30 \mathrm{~s}$ in a 10 -ml aqueous $\mathrm{NaClO}_{3}^{-}$solution $(1.05 \%$, vol/vol) containing $0.05 \%$ ( vol/vol) Triton X-100. Root tips were then rinsed twice in $10 \mathrm{ml}$ of autoclaved tap water, comminuted into suspensions, serially diluted, and plated in triplicate on $0.1 \times$ TSBA as described previously. After $48 \mathrm{~h}$ incubation at $25^{\circ} \mathrm{C}, 20$ discrete bacterial colonies ( $\geq 1 \mathrm{~mm}$ in size) were picked randomly from each of three plates per root tip from plates containing between 20 and 200 colonies according to a pattern developed by Boehm et al. (5). Bacterial strains were purified on $0.1 \times$ TSBA and stored in a $15 \%$ (vol/vol) sterile glycerol-water solution at $-75^{\circ} \mathrm{C}(42)$.

Inocula of the rhizobacterial strains for the radish bacterial leaf spot bioassays was produced at $24^{\circ} \mathrm{C}$ in TSB (Becton Dickinson) (50 ml/250-ml Erlenmeyer flask) on a rotary shaker $(90 \mathrm{rpm})$. The cultures were centrifuged once $(4,000 \times g, 10 \mathrm{~min})$ and the pellets were resuspended in autoclaved tap water. Each washed culture was inoculated into the heated $\left(60^{\circ} \mathrm{C}, 5\right.$ days $)$ composted pine bark mix to establish an initial population density of approximately $10^{7} \mathrm{CFU} \mathrm{g}^{-1}$ dry weight mix. $\mathrm{T}_{382}$ was used as an ISR positive control unless indicated otherwise. A granular dry powder preparation of $\mathrm{T}_{382}$ produced by Sylvan Bioproducts (Cabot, PA) was blended with heated $\left(5\right.$ days, $\left.60^{\circ} \mathrm{C}\right)$ potting mixes to achieve an initial population density of $10^{6} \mathrm{CFU}$ of $\mathrm{T}_{382} \mathrm{~g}^{-1}$ dry weight mix. The population of $\mathrm{T}_{382}$ added to mixes was verified by triplicate dilution plating on a Trichoderma selective medium (TSM; 10). The identity of $T_{382}$ was verified by examining phialides characteristic of $T$. hamatum under a dissecting microscope at $\times 200$ magnification (3). A specific random amplified polymorphic DNA marker developed by Abbasi et al. (2) was used to distinguish $\mathrm{T}_{382}$ from other isolates of $T$. hamatum recovered on TSM. Finally, a heated composted pine bark mix was used as a control that did not reduce the severity of leaf spot.

Rhizobacterial strains that significantly $(P \leq 0.05)$ reduced the mean severity of bacterial leaf spot to below the value observed on inoculated radish seedlings grown in the heated composted pine bark mix were tested in two additional bioassays. Strains that significantly $(P \leq 0.05)$ reduced the severity of bacterial leaf spot in at least one bioassay are referred to hereafter as suppressive to leaf spot. The number of strains was too large to be included in a single experiment. Therefore, the 11 most active strains were screened with the controls, $\mathrm{T}_{382}$, and acibenzolar- $S$ methyl (Actigard $50 \mathrm{WG}$, Syngenta Crop Protection, Greensboro, $\mathrm{NC} ; 50 \mu \mathrm{g} \mathrm{ml}^{-1}$ ) in three additional bioassays, as described previously.

The most active rhizobacterial strains were identified by partial sequencing of small subunit ribosomal RNA genes. To phylogenetically place these strains, 16S rDNA was amplified from genomic DNA and partially sequenced. Strains were grown on $0.1 \times$ TSBA for $24 \mathrm{~h}$ and transferred to $0.5 \mathrm{ml}$ of sterilized deionized water. Genomic DNA was extracted with the Qiagen DNeasy tissue kit (Qiagen, Valencia, CA) according to the manufacturer's instructions. The 16S rRNA genes were amplified using the oligonucleotide primers 8F (5'-AGAGTTTGATCCTGGCTCAG-3') and 519R (5'-GTATTACCGCGGCTGCTGG-3') (25). Polymerase chain reactions (PCR) were performed in a thermal cycler (PTC-100; MJ Research, Watertown, MA) in a total volume of $50 \mu \mathrm{l}$ containing $1 \times$ PCR buffer $(50 \mathrm{mM} \mathrm{KCl}, 10 \mathrm{mM}$ Tris- $\mathrm{HCl}$, and $0.1 \%$ Triton X-100, $\mathrm{pH} 9.0$ ), $1 \mathrm{mM}$ (each) of the four deoxyribonucleotide triphosphates (dTTP, dCTP, dGTP, and dATP), $1.5 \mathrm{mM} \mathrm{MgCl} 2,1 \mu \mathrm{M}$ each primer, $4 \mu \mathrm{g}$ of bovine serum albumin (Roche Diagnostics Corp., Indianapolis), and 2.5 units of Taq DNA polymerase (Perkin-Elmer, Norwalk, CT). The cycling program included an initial denaturation step at $95^{\circ} \mathrm{C} ; 30$ cycles of $94^{\circ} \mathrm{C}$ for $60 \mathrm{~s}, 54^{\circ} \mathrm{C}$ for $45 \mathrm{~s}$, and $70^{\circ} \mathrm{C}$ for $60 \mathrm{~s}$; and an 8 -min final extension step at $70^{\circ} \mathrm{C}$. PCR products were purified with QIAquick PCR purification columns (Qiagen, Chatsworth, CA) and sequenced using 3'-dye dideoxynucleotide triphosphate on a Perkin-Elmer ABI377 DNA sequencer. DNA sequences were assembled and edited using the Sequencer program (Gene Codes Corporation, Ann Arbor, MI). Preliminary analysis of the sequences was carried out by a BLAST search of the GenBank nucleic acid database (available online) using the program FASTA in the Genetic Computer Group (GCG) software package (Genetic Computer Group, Madison, WI).

The 16S rRNA sequences were aligned with known 16S rRNA sequences in the April 2001 database using the PILEUP program in GCG. The alignments were edited using the genetic data environment (43). Partial 16S rRNA gene sequences of isolates were submitted as GenBank (available online) Nos. AY191232, AY191233, AY191234, AY191235, AY191236, AY191237, AY191238, AY191239, and AY191241.

Interactions between $T_{382}$ and rhizobacteria that reduce the severity of bacterial leaf spot. The most active bacterial strain (Bacillus strain TH204) was tested in combination with $\mathrm{T}_{382}$ in three radish bioassays for bacterial leaf spot severity as described previously. $\mathrm{T}_{382}$ and Bacillus strain $\mathrm{TH} 204$ were added to the mixes at initial populations of $10^{6}$ and $10^{7} \mathrm{CFU} \mathrm{g} \mathrm{g}^{-1} \mathrm{mix}$, respectively, as described previously. Acibenzolar- $S$-methyl was used as the positive SAR control $(26,27)$. It was applied as a drench $48 \mathrm{~h}$ 
before seedlings were inoculated with $X$. campestris pv. armoraciae $704 \mathrm{~b}$. The heated composted pine bark mix served as control. Other control treatments included the natural composted pine bark mix (nonheated control) and radish seedlings not inoculated with $X$. campestris pv. armoraciae $704 \mathrm{~b}$ grown in the heated composted pine bark mix.

Populations of $X$. campestris pv. armoraciae $704 \mathrm{~b}$ and $\mathbf{T}_{382}$ in radish leaves. Foliar populations of $X$. campestris pv. armoraciae $704 \mathrm{~b}$ and of $\mathrm{T}_{382}$ were determined immediately after the plants had been rated for disease severity by collecting two replicate samples of leaves per treatment, each sample consisting of one leaf from each of five pots per treatment. These samples were placed in sterilized $10 \mathrm{mM}$ potassium phosphate bacterial dilution buffer $(\mathrm{pH} 7.2)$ in a ziploc freezer pouch using a 1:4 ratio (wt/wt) of fresh radish foliage to dilution buffer and then macerated with a ballbearing tissue grinder (Agdia, Inc., Elkhard, IN). This suspension was serially diluted in triplicate in dilution buffer and then plated on SPAS medium to detect X. campestris pv. armoraciae $704 \mathrm{~b}$ and on TSM medium to detect $\mathrm{T}_{382}$. Populations were determined as described previously.

Experimental design and statistical analyses. All bioassays were performed according to a completely randomized design. Each treatment was replicated five times (five pots per treatment), and 10 true leaves per pot were assayed. Mean bacterial leaf spot severity values and mean populations of $X$. campestris pv. armoraciae $704 \mathrm{~b}$ were determined, and treatment effects were evaluated using one- or two-way analysis of variance (ANOVA) depending on the experiment. In the large screening trials, the percent reduction in bacterial spot severity relative to the severity observed in the heated control was determined. Thereafter, the ratio of disease severity divided by the severity in the control was calculated and log-transformed to provide a linear scale and stabilize variances. Log-transformed values were analyzed with ANOVA to determine which bacterial strains produced a lower mean disease severity than the control. A reduction in disease severity corresponded to a negative log value. Minitab statistical software (Release 12, Minitab, Inc., State College, PA) was used for all analyses. If a significant $F$ test was obtained among treatments, significance of difference among means was determined using Fisher's least significant difference test.

\section{RESULTS}

Composts and rhizosphere microorganisms that suppressed the severity of bacterial spot. Only 1 of the 79 different natural batches of compost-amended potting mixes significantly $(P \leq$ 0.05 ) suppressed the severity of bacterial leaf spot over that observed on inoculated plants produced in the heated mix or the peat mix in each of two bioassays. This effective natural mix was prepared with a batch of composted biosolids produced by the Biosolids Composting Facility, Akron, OH. Potting mixes prepared with another batch of composted biosolids obtained from the same source and two other mixes prepared with composted biosolids from a different source did not significantly reduce the severity of bacterial leaf spot. The batch of composted pine bark mix received from Earthgro (Lebanon, CT) that was inoculated with the biocontrol agents $\mathrm{T}_{382}$ and $\mathrm{C}_{299}$ also consistently suppressed the severity of bacterial leaf spot over that observed in the control mixes (data not shown).

Utilizing the rinsed root tip procedure, 162 rhizobacterial strains were isolated on $0.1 \times$ TSBA from root tips harvested from the batch of composted pine bark mix that had been fortified with $\mathrm{T}_{382}$ and $\mathrm{C}_{299}$ and suppressed the severity of bacterial leaf spot. A total of 122 rhizobacterial strains were isolated on $0.1 \times$ TSBA by the same procedure from root tips harvested from the one natural batch of composted biosolids-amended mix that suppressed the disease. An additional 95 rhizobacterial strains were isolated on $0.1 \times \mathrm{TSBA}$ from heated $\left(10 \mathrm{~min}\right.$ at $\left.80^{\circ} \mathrm{C}\right)$ homogenates of root tips harvested from the same potting mix. Finally, an additional 159 rhizobacterial strains were isolated on $0.1 \times$ TSBA by the endophyte isolation procedure after surface sterilization of root tips. The 538 rhizobacterial strains were screened three times in the heated composted pine bark mix to assess their ability to suppress bacterial leaf spot.

Effective rhizobacterial strains that suppressed the severity of bacterial leaf spot were recovered from both potting mixes. A total of 49 of the 538 rhizobacterial strains $(9.1 \%)$ significantly reduced the severity of bacterial leaf spot in at least one of three initial bioassays. Seven of these were recovered from homogenates of rinsed root tips harvested from the composted pine bark mix that had been inoculated with the biocontrol agents $\mathrm{T}_{382}$ and $\mathrm{C}_{299}$, representing $4.3 \%$ of the total number of strains isolated on $0.1 \times$ TSBA from this source. Fifteen active strains were recovered from rinsed root tip homogenates of roots harvested from the batch of composted biosolids-amended potting mix that naturally suppressed the disease, representing $12.3 \%$ of the isolated strains, 14 were recovered from heat-treated root tip homogenates of this mix $(14.7 \%)$, and 13 were recovered by the endophyte isolation procedure from the same potting mix $(8.2 \%) . \mathrm{C}_{299}$ consistently failed to suppress the disease (data not shown).

Each of the 49 rhizobacterial strains that suppressed the severity of bacterial leaf spot, in addition to $\mathrm{T}_{382}$ and the plant activator acibenzolar- $S$-methyl, were tested in three radish bioassays to identify those treatments that most consistently reduced the severity of bacterial leaf spot. Eleven of fourty-nine strains suppressed disease in at least two of three radish bioassays, whereas $\mathrm{T}_{382}$ and acibenzolar- $S$-methyl suppressed disease in each of the three bioassays (data not shown). This group of 11 strains was compared with $\mathrm{T}_{382}$ and acibenzolar in three additional bioassays. Mean percent bacterial leaf spot severity, the percent reduction in mean bacterial spot severity, and the log-transformed ratio of bacterial spot severity relative to the severity of the inoculated control identified the strains that most consistently reduced the severity of bacterial spot (Table 1). The most effective strains (TH202, TH203A, TH204, and TH205) were identified as Bacillus sp. by partial $16 \mathrm{~S}$ rRNA gene sequencing. These four strains, in addition to $\mathrm{T}_{382}$ and the acibenzolar drench, significantly reduced the severity of bacterial spot in all three bioassays (Table 1). That is, the log-transformed ratio of disease severity was significantly less than 0. Efficacy of $\mathrm{T}_{382}$ and of Bacillus strain TH204 did not differ significantly from the drench with acibenzolar in these three bioassays. The most effective Bacillus strains (TH202 to TH205) were recovered from the batch of composted biosolids-amended mix that naturally suppressed the severity of bacterial spot. Finally, none of the rhizobacterial strains that were isolated from the biocontrol agent-fortified composted pine bark mix that suppressed bacterial leaf spot were as effective as $\mathrm{T}_{382}$. Only 4 of the 538 rhizobacterial strains $(0.7 \%)$ recovered from the SR-active compost-amended mixes consistently provided a significant degree of suppression of bacterial leaf spot of radish.

A further comparison of the efficacy of $\mathrm{T}_{382}$ and acibenzolar, based on five separate bacterial leaf spot bioassays, revealed that both treatments significantly suppressed the severity of the disease compared with disease on inoculated plants in the heated mixes (Table 2). Acibenzolar was significantly more effective than $\mathrm{T}_{382}$ in this analysis. The overall mean percent bacterial leaf spot severity value for inoculated plants in the natural potting mix was significantly $(P \leq 0.05)$ lower than that observed on plants grown in the batches of heated composted pine bark mix. This suggested that the natural mix had some effect on the disease as well.

Mixed inoculants. Efficacy of $\mathrm{T}_{382}$ alone in the composted pine bark mix relative to a mixed inoculum of $\mathrm{T}_{382}$ with Bacillus strain TH204 against bacterial spot was examined in three separate bioassays (Table 3). The acibenzolar drench consistently suppressed 
disease in all three bioassays. $\mathrm{T}_{382}$ alone also significantly $(P \leq$ $0.05)$ suppressed disease although only moderately in the third bioassay where it was not as effective as acibenzolar. The combined inoculum of $\mathrm{T}_{382}$ and Bacillus strain $\mathrm{TH} 204$ was also effective. However, the severity of bacterial spot for this treatment was significantly higher than that of $\mathrm{T}_{382}$ in the first assay and not significantly different from $\mathrm{T}_{382}$ alone in the remaining two assays. The percent disease reduction values across all three bioassays were $24.0 \%$ for the mixed inoculum, $34.4 \%$ for $\mathrm{T}_{382}$ alone, and $53.2 \%$ for the acibenzolar drench, revealing that the mixed inoculum was less effective than $\mathrm{T}_{382}$ alone. Acibenzolar was the most consistent treatment.

Populations of $X$. campestris pv. armoraciae $704 \mathrm{~b}$ and $T_{382}$. The effects of $\mathrm{T}_{382}$ and a drench with acibenzolar on the population of $X$. campestris pv. armoraciae $704 \mathrm{~b}$ in the foliage of radish plants with fully developed symptoms of bacterial leaf spot at 5 days after inoculation are presented in Table 4 . The population of $X$. campestris pv. armoraciae 704b in the foliage of seedlings produced in the heated composted pine bark mix was not significantly different from that in inoculated plants grown in the

TABLE 1. Suppression of bacterial leaf spot of radish induced by rhizobacterial strains isolated from potting mixes that naturally induced systemic resistance relative to ISR induced by Trichoderma hamatum $382\left(\mathrm{~T}_{382}\right)$ or SAR induced by a drench with acibenzolar-S-methyl

\begin{tabular}{|c|c|c|c|c|}
\hline Potting mix treatment ${ }^{\mathrm{a}}$ & $\begin{array}{c}\text { GenBank } \\
\text { Accession No. }\end{array}$ & $\begin{array}{l}\% \text { Mean bacterial } \\
\text { spot severity }\end{array}$ & $\begin{array}{c}\% \text { Reduction in mean bacterial } \\
\text { spot severity }\end{array}$ & $\begin{array}{l}\text { Log-transformed } \% \text { bacterial spot } \\
\text { severity of inoculated control }\end{array}$ \\
\hline Bacillus strain TH204 & AY191235 & 31.5 & 22.1 & -0.118 \\
\hline Bacillus strain TH202 & AY191234 & 33.4 & 15.9 & -0.093 \\
\hline Bacillus strain TH205 & AY191236 & 34.0 & 15.5 & -0.086 \\
\hline Pantoea endophytica B34 & AY191231 & 37.0 & 9.3 & -0.084 \\
\hline Klebsiella planticola B31 & ND & 35.9 & 12.4 & -0.081 \\
\hline Enterobacter asburiae $\mathrm{B} 24 \mathrm{~A}$ & AY191239 & 35.7 & 14.5 & -0.076 \\
\hline Bacillus strain TH220 & AY191233 & 36.0 & 8.3 & -0.063 \\
\hline Pseudomonas strain TE314 & AY191232 & 45.9 & 8.4 & -0.060 \\
\hline T. hamatum 382 & $\ldots$ & 31.5 & 29.5 & -0.171 \\
\hline Acibenzolar drench & $\ldots$ & 28.2 & 32.5 & -0.194 \\
\hline Control & $\ldots$ & $\ldots$ & $0^{\mathrm{e}}$ & $0^{\mathrm{e}}$ \\
\hline $\operatorname{LSD}_{0.05}{ }^{\mathrm{f}}$ & & & & 0.086 \\
\hline
\end{tabular}

${ }^{a}$ Systemic resistance active rhizobacterial strains were inoculated into a heated composted pine bark-amended potting mix at a population density of $10^{7}$ to $10^{8} \mathrm{CFU} \mathrm{g}{ }^{-1}$ dry weight mix; $\mathrm{T}_{382}$ was inoculated into the mix at a population of $10^{6} \mathrm{CFU} \mathrm{\textrm {g } ^ { - 1 }}$ mix and acibenzolar-S-methyl was applied as a drench $\left(50 \mu \mathrm{g} \mathrm{ml}^{-1}\right) 48 \mathrm{~h}$ prior to inoculation of the foliage with $X$. campestris pv. armoraciae $704 \mathrm{~b}$.

${ }^{b}$ Mean percent bacterial leaf spot severity of three bacterial leaf spot bioassays. The severity of the disease on the 10 first true leaves per pot (five pots per treatment) was determined 5 days after inoculation of 10-day-old seedlings (sprayed to runoff with a $3.3 \times 10^{6} \mathrm{CFU}^{-1}$ suspension of $X$. campestris pv. armoraciae $704 \mathrm{~b}$ ), based on a rating scale in which $1=$ symptomless, $2=$ few lesions to $10 \%$ of leaf area affected by lesions, $3=10$ to $25 \%$ of leaf area affected, $4=25$ to $50 \%$ of leaf area affected, $5=50$ to $75 \%$ of leaf area affected, and $6=>75 \%$ of leaf area affected or dead leaf. Disease ratings were transformed into percent bacterial spot severity values using midpoints of the range of percentages assigned to each point in the scale.

${ }^{\mathrm{c}}$ Percent reduction in mean bacterial spot severity $(R)$ calculated as mean percent severity of inoculated seedlings in the heated control mix $(H)$ minus the mean percent severity of the inoculated seedlings grown in the treated mix $(T)$ divided by the percent disease severity of inoculated seedlings in the heated mix (i.e., $R=[H-T] / H)$.

d Mean of log-transformed value of percent disease severity of inoculated seedlings grown in each treatment replication divided by percent disease severity of inoculated seedlings grown in the heated control mix. Log transformation was used to stabilize variances and produce a linear scale. The ratio for the inoculated heated control is 1.0 , which corresponds to a log of 0.0 . Negative log values indicate a reduction in disease severity.

${ }^{\mathrm{e}}$ Percent reduction in disease severity and $\log$ of the ratio of disease severities were 0 , by definition, for the inoculated heated control. The control was not used in the analysis.

${ }^{\mathrm{f}}$ Differences in mean log percent disease severity of the inoculated control greater than the LSD differed significantly $(P=0.05)$.

TABLE 2. Efficacy of Trichoderma hamatum $382\left(\mathrm{~T}_{382}\right)$ versus a drench with acibenzolar-S-methyl in a composted pine bark mix against bacterial leaf spot of radish caused by Xanthomonas campestris pv. armoraciae $704 \mathrm{~b}$, based on five bioassays

\begin{tabular}{|c|c|c|c|c|c|c|c|}
\hline \multirow[b]{2}{*}{ Potting mix treatment ${ }^{\mathrm{a}}$} & \multirow{2}{*}{$\begin{array}{l}\text { X. campestris pv. armoraciae } \\
704 \mathrm{~b} \text { inoculum }\end{array}$} & \multicolumn{6}{|c|}{ Mean $\%$ bacterial leaf spot severity ${ }^{\mathrm{c}}$} \\
\hline & & Bioassay I & Bioassay II & Bioassay III & Bioassay IV & Bioassay V & Overall mean ${ }^{\mathrm{d}}$ \\
\hline Control & - & 0 & 0 & 0 & 0 & 0 & 0 \\
\hline Control & + & 26.6 & 30.2 & 32.3 & 29.3 & 27.7 & 29.2 \\
\hline Heated control & + & 32.0 & 41.7 & 35.9 & 27.4 & 27.3 & 32.8 \\
\hline Heated mix $+\mathrm{T}_{382}$ & + & 21.8 & 24.2 & 23.0 & 12.9 & 21.8 & 20.7 \\
\hline Heated mix + acibenzolar drench & + & 14.6 & 21.7 & 14.4 & 11.0 & 18.1 & 16.0 \\
\hline
\end{tabular}

${ }^{a}$ Radish (Raphanus sativus L. cv. Cabernet) seeds were planted in a heated composted pine bark mix (heated control), a nonheated composted pine bark mix (natural control), a heated composted pine bark mix fortified with $10^{6} \mathrm{CFU}$ of $\mathrm{T}_{382} \mathrm{~g}^{-1}$ dry weight potting mix, and a heated composted pine bark mix drenched with acibenzolar-S-methyl solution $\left(50 \mu \mathrm{g} \mathrm{m}^{-1}\right) 48 \mathrm{~h}$ prior to spray inoculation of the foliage with X. campestris pv. armoraciae $704 \mathrm{~b}$.

${ }^{\mathrm{b}}+=$ radish foliage sprayed to runoff 10 days after seeding with a $3.3 \times 10^{6} \mathrm{CFU} \mathrm{ml}^{-1}$ suspension of $X$. campestris pv. armoraciae $704 \mathrm{~b}$ that also contained $0.02 \%$ Silwet L-77. - = radish foliage sprayed with autoclaved tap water containing $0.02 \%$ Silwet L-77.

${ }^{c}$ Mean percent bacterial leaf spot severity for five bacterial leaf spot bioassays. Percent bacterial leaf spot severity of 10 first true leaves per pot (five pots per treatment) was determined 15 days after seeding based on a rating scale in which $1=$ symptomless, $2=$ few lesions to $10 \%$ of leaf area affected by lesions, $3=10$ to $25 \%$ of leaf area affected, $4=25$ to $50 \%$ of leaf area affected, $5=50$ to $75 \%$ of leaf area affected, and $6=>75 \%$ of leaf area affected or dead leaf. Disease ratings were transformed into percent bacterial spot severity values using midpoints of the range of percentages assigned to each point in the scale.

d Overall mean percent bacterial leaf spot severity determined for bacterial spot severity values across the replicates and bioassays.

${ }^{\text {e }}$ Differences in overall mean percent bacterial leaf spot severity values greater than the LSD differed significantly $(P=0.05)$. Analysis was based on using each bioassay as a block. Thus, there were two factors, treatment and block, for the analysis of variance. There was no significant interaction of block and treatment. 
natural control mix. In all three bioassays, the population of $X$. campestris pv. armoraciae $704 \mathrm{~b}$ isolated from the foliage of plants that had been drenched with acibenzolar was significantly $(P \leq 0.05)$ lower (by one half to one order of magnitude) than in leaves of inoculated plants grown in the heated control mix. $\mathrm{T}_{382}$ also significantly reduced the population of $X$. campestris pv. armoraciae $704 \mathrm{~b}$ in two of three bioassays. Thus, acibenzolar more consistently reduced the population of $X$. campestris $\mathrm{pv}$. armoraciae $704 \mathrm{~b}$ in radish leaves.

$\mathrm{T}_{382}$ was not recovered from the foliage of radish seedlings based on dilution plating of leaf homogenates on TSM. The mean population in potting mixes that had been inoculated with $\mathrm{T}_{382}$ remained $>5.5 \times 10^{5} \mathrm{CFU} \mathrm{g}^{-1}$ dry weight mix throughout the experiments as shown previously for such potting mixes (22). $T_{382}$ was not recovered from control mixes that had not been inoculated with $\mathrm{T}_{382}$. Its identity, based on colonies isolated on TSM, was verified by PCR. In conclusion, $\mathrm{T}_{382}$ and $X$. campestris pv. armoraciae
$704 \mathrm{~b}$ remained spatially separated on radish plants throughout these bioassays, suggesting that the suppressive effect induced by $\mathrm{T}_{382}$ against bacterial leaf spot was systemic in nature.

\section{DISCUSSION}

This work revealed that suppression of bacterial leaf spot of radish in compost-amended substrates is a rare phenomenon. Only 1 of the 79 natural batches of composts tested in potting mixes suppressed the severity of bacterial leaf spot. The second active batch had been inoculated with $\mathrm{T}_{382}$, which by itself can induce SR in radish against this disease (16). Part, if not all, of the SR activity provided by this batch of compost most probably was due to $\mathrm{T}_{382}$, because rhizobacterial strains recovered from this mix did not consistently suppress the severity of the disease when inoculated into the heated potting mix. Lack of suppression in the other 78 batches of compost-amended mixes probably was not due

TABLE 3. Efficacy of Trichoderma hamatum $382\left(\mathrm{~T}_{382}\right)$ used singly or in combination with Bacillus strain TH204 against bacterial leaf spot of radish caused by Xanthomonas campestris pv. armoraciae $704 \mathrm{~b}$

\begin{tabular}{|c|c|c|c|c|c|}
\hline \multirow[b]{2}{*}{ Potting mix treatment ${ }^{\mathrm{a}}$} & \multirow{2}{*}{$\begin{array}{l}\text { X. campestris pv. armoraciae } \\
704 \mathrm{~b} \text { inoculum }\end{array}$} & \multicolumn{3}{|c|}{ Mean $\%$ bacterial leaf spot severity ${ }^{c}$} & \multirow[b]{2}{*}{$\%$ Disease reduction $^{\mathrm{d}}$} \\
\hline & & Assay I & Assay II & Assay III & \\
\hline Control & - & 0.0 & 0.0 & 0.0 & ... \\
\hline Control & + & 24.4 & 34.2 & 24.0 & 1.3 \\
\hline Heated control & + & 29.0 & 30.2 & 25.1 & $\ldots$ \\
\hline Heated mix $+\mathrm{T}_{382}$ & + & 14.4 & 18.4 & 20.7 & 34.4 \\
\hline \multicolumn{6}{|l|}{ Heated mix $+\mathrm{T}_{382}+$} \\
\hline
\end{tabular}

${ }^{a}$ Radish (Raphanus sativus L. cv. Cabernet) seeds were planted in a heated composted pine bark mix (heated control), a nonheated composted pine bark mix (natural control), a heated composted pine bark mix fortified with $10^{6} \mathrm{CFU}$ of $\mathrm{T}_{382} \mathrm{~g}^{-1}$ dry weight potting mix, a heated composted pine bark mix fortified with $10^{7}$ to $10^{8} \mathrm{CFU}$ of Bacillus strain TH204 and $10^{6} \mathrm{CFU}$ of $\mathrm{T}_{382} \mathrm{~g}^{-1}$ dry weight potting mix, and a heated composted pine bark mix drenched with acibenzolar-S-methyl solution $\left(50 \mu \mathrm{g} \mathrm{ml}^{-1}\right) 48 \mathrm{~h}$ before inoculation of the foliage with X. campestris pv. armoraciae $704 \mathrm{~b}$.

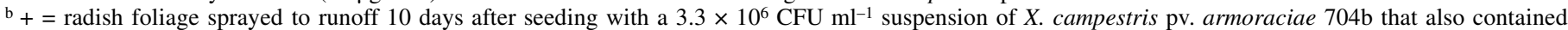
$0.02 \%$ Silwet L-77. - = radish foliage sprayed with autoclaved tap water containing $0.02 \%$ Silwet L-77.

${ }^{\mathrm{c}}$ Mean percent bacterial leaf spot severity for three bacterial leaf spot bioassays. Percent bacterial leaf spot severity on the first 10 true leaves per pot (five pots per treatment) was determined 5 days after inoculation of 10-day-old seedlings sprayed to runoff with a $3.3 \times 10^{6} \mathrm{CFU} \mathrm{ml}^{-1}$ suspension of $X$. campestris pv. armoraciae $704 \mathrm{~b}$, based on a rating scale in which $1=$ symptomless, $2=$ few lesions to $10 \%$ of leaf area affected by lesions, $3=10$ to $25 \%$ of leaf area affected, $4=25$ to $50 \%$ of leaf area affected, $5=50$ to $75 \%$ of leaf area affected, and $6=>75 \%$ of leaf area affected or dead leaf. Disease ratings were transformed into percent bacterial spot severity values using midpoints of the range of percentages assigned to each point in the scale.

${ }^{\mathrm{d}}$ Percent reduction in mean bacterial leaf spot severity $(R)$ was calculated as the mean percent severity of pathogen-inoculated seedlings grown in the heated control mix $(H)$ minus the mean percent severity of the pathogen-inoculated seedlings grown in the treated mix $(T)$ divided by the percent severity of pathogen-inoculated seedlings in the heated mix (i.e., $R=[H-T] / H$ ).

e Differences of mean bacterial spot severity larger than the LSD (within and across columns) are significantly different $(P=0.05)$. Analysis was based on using each bioassay as a block. Thus, there were two factors, treatment and block, for the analysis of variance. Because of a significant interaction, assay/treatment means are compared within and between bioassays.

TABLE 4. Effect of Trichoderma hamatum $382\left(\mathrm{~T}_{382}\right)$ inoculated into a composted pine bark potting mix on the population of Xanthomonas campestris pv. armoraciae $704 \mathrm{~b}$ isolated from radish foliage in three bioassays

\begin{tabular}{|c|c|c|c|c|}
\hline \multirow[b]{2}{*}{ Potting mix treatment ${ }^{\mathrm{a}}$} & \multirow{2}{*}{$\begin{array}{l}\text { X. campestris pv. armoraciae } \\
704 \mathrm{~b} \text { inoculum }{ }^{\mathrm{b}}\end{array}$} & \multicolumn{3}{|c|}{ Foliar population of $X$. campestris pv. armoraciae $704 \mathrm{~b}\left(\log \mathrm{CFU} \mathrm{^{-1 }}\right.$ fresh weight) } \\
\hline & & Bioassay I & Bioassay II & Bioassay III \\
\hline Control & - & $<1.5$ & $<1.5$ & $<1.5$ \\
\hline Control & + & 8.1 & 9.3 & 7.4 \\
\hline Heated control & + & 7.8 & 9.4 & 7.4 \\
\hline Heated mix $+\mathrm{T}_{382}$ & + & 7.5 & 8.3 & 6.9 \\
\hline Heated mix + acibenzolar drench & + & 7.2 & 8.3 & 6.4 \\
\hline
\end{tabular}

${ }^{a}$ Radish (Raphanus sativus L. cv. Cabernet) seeds were planted in a heated composted pine bark mix (heated control), a nonheated composted pine bark mix (natural control), a heated composted pine bark mix fortified with $10^{6} \mathrm{CFU}$ of $\mathrm{T}_{382} \mathrm{~g}^{-1}$ dry weight potting mix, and a heated composted pine bark mix drenched with acibenzolar-S-methyl solution $\left(50 \mu \mathrm{g} \mathrm{ml}^{-1}\right) 48 \mathrm{~h}$ prior to inoculation of the foliage with X. campestris pv. armoraciae $704 \mathrm{~b}$.

$\mathrm{b}+=$ radish foliage sprayed to runoff 10 days after seeding with a $3.3 \times 10^{6} \mathrm{CFU} \mathrm{ml}^{-1}$ suspension of $X$. campestris pv. armoraciae $704 \mathrm{~b}$ that contained $0.02 \%$ Silwet L-77. - = radish foliage sprayed with autoclaved tap water containing 0.02\% Silwet L-77.

${ }^{c}$ The foliar population of $X$. campestris pv. armoraciae 704b was determined by macerating five first true leaves randomly collected from each pot in each treatment in bacterial dilution buffer followed by dilution plating on sucrose peptone agar containing streptomycin sulfate $\left(150 \mu \mathrm{g} \mathrm{ml} l^{-1}\right)$. Data represent mean population values for two sets of leaf samples collected from each treatment for each of three bioassays. A separate analysis of variance was performed for each bioassay. The detection limit for X. campestris pv. armoraciae $704 \mathrm{~b}$ was $\log 1.5 \mathrm{CFU} \mathrm{g}^{-1}$ fresh weight foliage. 
to masking of suppressive effects induced by fertility factors associated with the different composts or due to lack of stability. The concentration of essential plant nutrients in the foliage of radish seedlings produced in potting mixes amended with different batches of composts were within recommended guidelines for this crop and did not differ significantly. Furthermore, all composts tested in this work had been decomposed to a high degree of stability so that lack of stability, which can repress biological control of soilborne plant pathogens (18), was avoided. Thus, factors other than fertility or stability played the dominant role in the suppressive effect. Because heating destroyed the suppressive effect and inoculation with some of the specific strains restored efficacy, it may be concluded that microorganisms in the one batch of composted biosolids-amended potting mix that naturally suppressed bacterial leaf spot were most likely responsible for the suppressive effect against the disease.

The spectrum of bacterial taxa represented by the active rhizobacterial strains recovered from radish roots (Table 1), in general, is in agreement with taxa reported to harbor such strains based on field soil studies $(51,52)$. However, only a very small proportion of the rhizobacterial strains $(<1 \%)$ recovered from radish roots harvested from the two active compost-amended potting mixes suppressed bacterial leaf spot of radish. Interestingly, more active bacteria were isolated on TSBA from the composted biosolids mix that naturally suppressed the disease than from the composted pine bark mix that had been fortified with $\mathrm{T}_{382}$. In contrast, $25 \%$ of the rhizobacterial strains representing these same bacterial taxa that were recovered earlier on $0.1 \times$ TSBA from similar compostamended mixes induced suppression of Pythium damping-off $(5,6)$. Thus, the low incidence of suppression of bacterial leaf spot observed in this work among the 79 natural batches of compostamended mixes probably was due to the low frequency by which the specific rhizobacteria that are capable of inducing systemic resistance in plants recolonized these composts after peak heating. Pythium root rot is suppressed by a great diversity of biocontrol agents colonizing such compost-amended mixes, and it is not surprising that this effect is consistent from batch to batch as long as composts have been colonized to induce microbiostasis $(5,8,28)$.

The incidence of natural suppression of bacterial spot observed in this work among compost-amended mixes $(<2 \%)$ also was much lower than the value of $19.8 \%$ reported for natural suppression of Rhizoctonia damping-off in compost-amended mixes (22). The abundance of fungal taxa that colonize composts after peak heating and that also have the ability to parasitize and eradicate sclerotia of Rhizoctonia solani is affected by the environment in which composts are produced (23). For example, composts produced in closed in-vessel systems are much less likely to be colonized naturally by biocontrol agents capable of inducing suppression to Rhizoctonia damping-off than the same compost produced directly adjacent to forest litter (23). This specific deficiency in colonization of composts by biocontrol agents capable of providing biological control of Rhizoctonia damping-off can be avoided through controlled inoculation of composts with such microorganisms after peak heating $(24,32)$. The data from this work and that of Pharand et al. (33) reveal that it should be possible to improve on the natural incidence of compost-induced systemic resistance against diseases of aboveground plant parts through such a strategy of biological control.

The biocontrol agent $T_{382}$ more than likely provided most of its activity against bacterial spot of radish by inducing systemic resistance against the disease because it remained spatially separated on the plant from the pathogen X. campestris pv. armoraciae 704b. This finding supports earlier reports that isolates of Trichoderma can induce systemic resistance in plants against diseases $(20,40$, 55). Even though $\mathrm{T}_{382}$ was effective in most bioassays in this work, it was significantly less effective than a drench with acibenzolar-S-methyl. Our attempts to develop a mixture of biocontrol agents that was more effective than single strains, as reported by Raupach and Kloepper (38), failed. Efficacy of $\mathrm{T}_{382}$ when combined with Bacillus strain TH204 was not significantly different from that of $\mathrm{T}_{382}$ alone. An analysis of factors that could contribute to this effect was beyond the scope of this work.

Mixed biocontrol agent inoculants undoubtedly will need to be developed to produce substrates that more consistently induce systemic resistance in plants, as reported earlier for suppression of Rhizoctonia damping-off (24). The temperature of compostamended mixes immediately after their formulation often is in the range of 35 to $40^{\circ} \mathrm{C}$. Trichoderma isolates, including $\mathrm{T}_{382}$, cannot tolerate such elevated temperatures for more than a few hours $(\mathrm{H}$. A. J. Hoitink, unpublished data). In contrast, high temperature tolerant Bacillus strains that can serve as biocontrol agents of soilborne plant pathogens in compost-amended substrates already have been developed (32). A second reason for utilization of mixed cultures is that not all types of composts serve as suitable substrates for Trichoderma (14), whereas Bacillus and other bacterial taxa reported to harbor strains that can induce systemic resistance $(51,52)$ are able to colonize several different types of composted substrates $(4,29,31,46,47)$. Finally, mixed cultures could be developed that induce biological control through different mechanisms and might improve effectiveness as proposed by Whipps (53).

The degree of protection from disease provided by the ISR active $\mathrm{T}_{382}$-fortified compost-amended potting mix in this work seemed small. It reduced the severity of bacterial leaf spot by only $34.4 \%$. In contrast, the SAR inducer acibenzolar reduced the severity by $53.2 \%$. One might conclude from these findings that farmers might not be interested in the degree of protection provided by $\mathrm{T}_{382}$. Field-scale trials may prove, however, that this low level of protection will be capable of avoiding epidemics. Thus, field level information will need to be developed to determine the potential for economic returns for this approach to disease control for some crops. On woody ornamentals, however, this low degree of control may prove adequate for bacterial leaf spot diseases, which are difficult to control, in general. Furthermore, total control of such diseases is not necessary on woody ornamentals.

\section{ACKNOWLEDGMENTS}

This research was supported by grants from the Ohio Floriculture Foundation (Columbus, Ohio), DCM Corporation (St. Katelijne-Waver, Belgium), The Ohio Agricultural Research and Development Center (Wooster, OH), and from BARD grant US-3109-99, United States-Israel Binational Agricultural Research and Development Fund. Salaries and research support were provided by state and federal funds to The Ohio Agricultural Research and Development Center, The Ohio State University. We thank Sellew and Associates, (Carlisle, MA), Paygro, Inc. (South Charleston, OH), Kurtz Bros., Inc., Compost (Groveport, OH), Fresh Aire Farms (Union City, OH), and Sungro Horticulture (McCormick, SC) for providing compost samples and Sylvan Bioproducts (Cabot, PA) for supplying $\mathrm{T}_{382}$ inoculum. We also thank A. E. Dorrance and B. B. McSpadden Gardener for reviewing this manuscript.

\section{LITERATURE CITED}

1. Abbasi, P. A., Al-Dahami, J., Sahin, F., Hoitink, H. A. J., and Miller, S. A. 2002. Effect of compost amendments on disease severity and yield of tomato in conventional and organic production systems. Plant Dis. 86:156-161.

2. Abbasi, P. A., Miller, S. A., Meulia, T., Hoitink, H. A. J., and Kim, J. 1999. Precise detection and tracing of Trichoderma hamatum 382 in compost-amended potting mixes by using molecular markers. Appl. Environ. Microbiol. 65:5421-5426.

3. Bissett, J. 1991. A revision of the genus Trichoderma. II. Infragenic classification. Can. J. Bot. 69:2357-2372.

4. Blanc, M., Marilley, L., Beffa, T., and Aragno, M. 1997. Rapid identification of heterotrophic, thermophilic, spore-forming bacteria isolated from hot composts. Int. J. Syst. Bacteriol. 47:1246-1248.

5. Boehm, M. J., Madden, L. V., and Hoitink, H. A. J. 1993. Effect of organic matter decomposition level on bacterial species diversity and composition in relationship to Pythium damping-off severity. Appl. Environ. Microbiol. 59:4171-4179. 
6. Boehm, M. J., Wu, T., Stone, A. G., Kraakman, B., Iannotti, D. A., Wilson, G. E., Madden, L. V., and Hoitink, H. A. J. 1997. Crosspolarized magic-angle spinning ${ }^{13} \mathrm{C}$ nuclear magnetic resonance spectroscopic characterization of soil organic matter relative to culturable bacterial species composition and sustained biological control of Pythium root rot. Appl. Environ. Microbiol. 63:162-168.

7. Charest, P. M., Ouellette, G. B., and Pauzé, F. J. 1984. Cytological observations of early infection process of Fusarium oxysporum f. sp. radicis-lycopersici. Can. J. Bot. 62:1232-1244.

8. Chen, W., Hoitink, H. A. J., and Madden, L. V. 1988. Microbial activity and biomass in container media for predicting suppressiveness to damping-off caused by Pythium ultimum. Phytopathology 78: 1447-1450.

9. Chen, Y. 2003. Nuclear magnetic resonance, infra-red and pyrolysis: Application of spectroscopic methodologies to maturity determination of composts. Comp. Sci. Util. 11:152-168.

10. Chung, Y. R., and Hoitink, H. A. J. 1990. Interactions between thermophilic fungi and Trichoderma hamatum in suppression of Rhizoctonia damping-off in a bark compost-amended container medium. Phytopathology 80:73-77.

11. Clulow, S. A., Stewart, H. E., Dashwood, E. P., and Wastie, R. L. 1995. Tuber surface microorganisms influence the susceptibility of potato tubers to late blight. Ann. Appl. Biol. 126:33-43.

12. Cohen, R., Chefetz, B., and Hadar, Y. 1998. Suppression of soil-borne pathogens by composted municipal solid waste. Pages 113-130 in: Beneficial Co-Utilization of Agricultural, Municipal and Industrial ByProducts. S. Brown, J. S. Angle, and L. Jacobs, eds. Kluwer Academic Publishers, Dordrecht, the Netherlands.

13. De Ceuster, T. J. J., and Hoitink, H. A. J. 1999. Prospects for composts and biocontrol agents as substitutes for methyl bromide in biological control of plant diseases. Comp. Sci. Util. 7:6-15.

14. Hadar, Y., and Gorodecki, B. 1991. Suppression of germination of sclerotia of Sclerotium rolfsii in compost. Soil Biol. Biochem. 23:303306.

15. Hammerschmidt, R., Métraux, J.-P., and van Loon, L. C. 2001. Inducing resistance: A summary of papers presented at the First International Symposium on Induced Resistance to Plant Diseases. Eur. J. Plant Pathol. 107:1-6.

16. Han, D. Y., Coplin, D. L., Bauer, W. D., and Hoitink, H. A. J. 2000. A rapid bioassay for screening rhizosphere microorganisms for their ability to induce systemic resistance. Phytopathology 90:327-332.

17. Heil, M., and Baldwin, I. T. 2002. Fitness costs of induced resistance: Emerging experimental support for a slippery concept. Trends Plant Sci. 7:61-67.

18. Hoitink, H. A. J., and Boehm, M. J. 1999. Biocontrol within the context of soil microbial communities: A substrate-dependent phenomenon. Annu. Rev. Phytopathol. 37:427-446.

19. Hoitink, H. A. J., Stone, A. G., and Han, D. Y. 1997. Suppression of plant diseases by composts. HortScience 32:184-187.

20. Howell, C. R. 2003. Mechanisms employed by Trichoderma species in the biological control of plant diseases: The history and evolution of current concepts. Plant Dis. 87:4-10.

21. Krause, M. S., De Ceuster, T. J. J., Han, D. Y., Musselman, C. A., and Hoitink, H. A. J. 1998. Systemic acquired resistance induced by composts: A highly specific phenomenon. (Abstr.) Phytopathology 88(suppl.):S49-S50.

22. Krause, M. S., Madden, L. V., and Hoitink, H. A. J. 2001. Effect of potting mix microbial carrying capacity on biological control of Rhizoctonia damping-off of radish and Rhizoctonia crown and root rot of poinsettia. Phytopathology 91:1116-1123.

23. Kuter, G. A., Nelson, E. B., Hoitink, H. A. J., and Madden, L. V. 1983. Fungal populations in container media amended with composted hardwood bark suppressive and conducive to Rhizoctonia damping-off. Phytopathology 73:1450-1456.

24. Kwok, O. C. H., Fahy, P. C., Hoitink, H. A. J., and Kuter, G. A. 1987. Interactions between bacteria and Trichoderma hamatum in suppression of Rhizoctonia damping-off in bark compost media. Phytopathology 77:1206-1212.

25. Lane, D. J. 1991. 16S/23S rRNA sequencing. Pages 115-175 in: Nucleic Acid Techniques in Bacterial Systematics. E. Stackebrandt and M. Goodfellow, eds. John Wiley \& Sons, New York.

26. Lawton, K. A., Friedrich, L., Hunt, M., Weymann, K., Delaney, T., Kessmann, H., Staub, T., and Ryals, J. 1996. Benzothiadiazole induces resistance in Arabidopsis by activation of the systemic acquired resistance signal transduction pathway. Plant J. 10:71-82.

27. Louws, F. J., Wilson, M., Campbell, H. L., Cuppels, D. A., Jones, J. B., Shoemaker, P. B., Sahin, F., and Miller, S. A. 2001. Field control of bacterial spot and bacterial speck of tomato using a plant activator. Plant Dis. $85: 481-488$
28. Mandelbaum, R., and Hadar, Y. 1990. Effects of available carbon source of microbial activity and suppression of Pythium aphanidermatum in compost and peat container media. Phytopathology 80:794-804.

29. Michel, F. C., Jr., Marsh, T. L., Reddy, C. A. 2002. Characterization of microbial community structure during composting using analysis of terminal restriction fragment length polymorphisms of $16 \mathrm{~S}$ rRNA genes. Pages 25-42 in: Microbiology of Composting. H. Insam, N. Riddech, and S. Klammer, eds. Springer-Verlag, Heidelberg.

30. Musson, G., McInroy, J. A., and Kloepper, J. W. 1995. Development of delivery systems for introducing endophytic bacteria into cotton. Biocontrol Sci. Technol. 5:407-416.

31. Peters, S., Koschinsky, S., Schwieger, F., and Tebbe, C. C. 2000. Succession of microbial communities during hot composting as detected by PCR-single-strand-conformation polymorphism-based genetic profiles of small-subunit rRNA genes. Appl. Environ. Microbiol. 66:930-936.

32. Phae, C. G., Saski, M., Shoda, M., and Kubota, H. 1990. Characteristics of Bacillus subtilis isolated from composts suppressing phytopathogenic microorganisms. Soil Sci. Plant Nutr. 36:575-586.

33. Pharand, B., Carisse, O., and Benhamou, N. 2002. Cytological aspects of compost-mediated induced resistance against Fusarium crown and root rot in tomato. Phytopathology 92:424-438.

34. Pieterse, C. M. J., and van Loon, L. C. 1999. Salicylic acid-independent plant defense pathways. Trends Plant Sci. 4:52-58.

35. Precheur, R. J. 2000. Ohio vegetable production guide. The Ohio State Univ. Ext. Bull. 672.

36. Press, C. M., Loper, J. E., and Kloepper, J. W. 2001. Role of iron in rhizobacteria-mediated induced systemic resistance of cucumber. Phytopathology 91:593-598.

37. Puustjarvi, V., and Robertson, R. A. 1975. Physical and chemical properties. Pages 23-28 in: Peat in Horticulture. D. W. Robinson and J. G. D. Lamb, eds. Academic Press, New York.

38. Raupach, G. S., and Kloepper, J. W. 1998. Mixtures of plant growthpromoting rhizobacteria enhance biological control of multiple cucumber pathogens. Phytopathology 88:1158-1164.

39. Sahin, F., and Miller, S. A. 1996. Occurrence and identification of a bacterial spot disease of radish in Ohio. (Abstr.) Phytopathology 86(suppl.):S79.

40. Sid Ahmed, A., Sánchez, C. P., and Candela, M. E. 2000. Evaluation of induction of systemic resistance in pepper plants (Capsicum annuum) to Phytophthora capsici using Trichoderma harzianum and its relation to capsidiol accumulation. Eur. J. Plant Pathol. 106:817-824.

41. Sikora, L. J., and Szmidt, R. A. K. 2000. Nitrogen sources, mineralization rates, and nitrogen nutrition benefits to plants from composts. Pages 287-306 in: Compost Utilization in Horticultural Cropping Systems. P. J. Stofella and B. A. Kahn, eds. Lewis Publishers, New York.

42. Sleesman, J. P., and Leben, C. 1978. Preserving phytopathogenic bacteria at $-70^{\circ} \mathrm{C}$ or with silica gel. Plant Dis. 62:910-913.

43. Smith, S. W., Overbeek, R., Woese, C. R., Gilbert, W., and Gillevet, P. M. 1994. The genetic data environment an expandable GUI for multiple sequence-analysis. Comput. Appl. Biosci. 10:671-675.

44. Stone, A. G., Traina, S. J., and Hoitink, H. A. J. 2001. Particulate organic matter composition and Pythium damping-off of cucumber. Soil Sci. Soc. Am. J. 65:761-770.

45. Stone, A. G., Vallad, G. E., Cooperband, L. R., Rotenberg, D., Darby, H. M., James, R. V., Stevenson, W. R., and Goodman, R. M. 2003. Effect of organic amendments on soilborne and foliar diseases in field-grown snap bean and cucumber. Plant Dis. 87:1037-1042.

46. Strom, P. F. 1985. Effects of temperature on bacterial diversity in thermophilic solid waste composting. Appl. Environ. Microbiol. 50:899905 .

47. Strom, P. F. 1985. Identification of thermophilic bacteria solid waste composting. Appl. Environ. Microbiol. 50:906-913.

48. Thompson, W., Leege, P., Millner, P., and Watson, M. E. 2003. Test methods for the examination of composting and compost. TMECC website. Published online by The U.S. Composting Council.

49. Ton, J., Van Pelt, J. A., Van Loon, L. C., and Pieterse, C. M. J. 2002. The Arabidopsis ISRI locus is required for rhizobacteria-mediated induced systemic resistance against different pathogens. Plant Biol. 4:224-227.

50. Tränkner, A. 1992. Use of agricultural and municipal organic wastes to develop suppressiveness to plant pathogens. Pages 35-42 in: Biological Control of Plant Diseases. E. C. Tjamos, G. C. Papavizas, and R. J. Cook, eds. Plenum Press, New York.

51. van Loon, L. C., Bakker, P. A. H. M., and Pieterse, C. M. J. 1998. Systemic resistance induced by rhizosphere bacteria. Annu. Rev. Phytopathol. 36:453-483.

52. Wei, G., Kloepper, J. W., and Tuzun, S. 1991. Induction of systemic resistance of cucumber to Colletotrichum orbiculare by select strains of plant growth-promoting rhizobacteria. Phytopathology 81:728-733. 
53. Whipps, J. M. 2001. Microbial interactions and biocontrol in the rhizosphere. J. Exp. Bot. 52:487-511.

54. Yan, Z., Reddy, M. S., Ryu, C.-M., McInroy, J. A., Wilson, M., and Kloepper, J. W. 2002. Induced systemic protection against tomato late blight elicited by plant growth-promoting rhizobacteria. Phytopathology 92:1329-1333.

55. Yedidia, I., Benhamou, N., and Chet, I. 1999. Induction of defense responses in cucumber plants (Cucumis sativus L.) by the biocontrol agent Trichoderma harzianum. Appl. Environ. Microbiol. 65:10611070.

56. Zhang, W., Dick, W. A., and Hoitink, H. A. J. 1996. Compost-induced systemic acquired resistance in cucumber to Pythium root rot and anthracnose. Phytopathology 86:1066-1070.

57. Zhang, W., Han, D. Y., Dick, W. A., Davis, K. R., and Hoitink, H. A. J. 1998. Compost and compost water extract-induced systemic acquired resistance in cucumber and arabidopsis. Phytopathology 88:450-455. 